\title{
Despondency of Women as Portrayed in Shashi Deshpande's That Long Silence
}

\author{
S. Surya \\ M. Phil English PG Research \& Department of English, Laxminarayana Arts \& Science College for Women, Thokkampatty, \\ Dharmapuri (D.T), India
}

\begin{abstract}
Indian women writers of the twentieth and twenty first centuries always try to raise the issues related to women with a fresh perspective. These women writers have presented life through literature with great vividness. Among the feminist writers, Shashi Deshpande gets a prominent place in later part of the twentieth century. Deshpande's novels often deal with the problem and sufferings of women in middle class family, which reflects the realistic picture of the contemporary middle class family life. The present article clearly declares the despondency state of middle class women as portrayed in Deshpande's That Long Silence. Jaya is the main character of this novel. The silence between Jaya and her husband further deteriorates the situation. She realizes at the end that she should break the silence and try to achieve her identity as an individual through self-realization and self-assertion.
\end{abstract}

Keywords - Identity, Middle class Women, Woman

Status, Self-realization.

\section{BACKGROUND OF THE STUDY}

Despondency means depression of spirits from loss of courage. It can include not only sadness, but feelings of hopelessness. In that state one would feel deserted and lonely unable to decide anything and everything around the person seems dark. It is a state characterized by low spirits and a loss of hope. It is a kind of extreme sadness. It also includes feelings of profound hopelessness, dejection, discouragement or gloom and inadequacy. It actually comes out of a collection with reality. The adjective 'despondent' is from Latin term 'despondens' from 'despondere' 'to lose courage, give up'. It is also known by a term 'acedia' which was traditionally listed as one of the 'seven deadly sins'.

Aldous Huxley, the author of Brave New world, thought it was one of the main of the diseases of the modern age. Everyone feels sad or low sometimes, but these feelings usually pass with a little time. Sadness is only one small part of depression and some people with depression may not feel sadness at all. Despondency is one of the most widespread emotional problems and it undoubtedly has many causes. When one is stressed or despondent, experiencing positive emotions can make it more likely that he will find creative solutions to his problems. Even though Good and evil occur in all lives, what separates people from that of evil things or unhappiness is a matter of attitude. Everyone must tent to see their lives in more position terms, even when trouble comes their way.

The present article declares the despondency state of middle class women as portrayed in Deshpande's That Long Silence. It is the third novel of Shashi Deshpande. This novel is the first of her novels to be published in abroad. Deshpande realistically adopting different modes of narration and gradually narrating one incident after another and moves back and forth thematically till the end of the novel. The representation of real life experience is one of the reasons for the success of her novels. That long silence is an expression of the silence of the modern Indian housewife. Silence is a patriarchal symbol.

Jaya is the main character of this novel. Before marriage Jaya led an ordinary carefree life because of her father's fostering love and care. Only after her marriage, she began to realize her state of despondency in every stage in her life as well as other women in the society. The novel opens in the Old Dadar flat where Jaya and her husband Mohan went back to live in the flat from their palatial house. The children Rahul and Rati are away from the house for a long tour with their family friends. Jaya in the mean time goes deep into contemplation of her childhood stage and her past life. After a long period of married life, it is for the first time Jaya thought of herself and her individuality. Adele observes her mentality by stating "Jaya finds her normal routine so disrupted that for the first time she can look at her life and attempt to decide who she really is" (3).

During her stay at Dadar flat, Jaya introspects at her true identity. The loneliness of a lady, according to the novelist, is no mental abnormality, but paves the way for the new woman's quest for self- discovery. The loneliness at Dadar flat gives Jaya space for self-discovery. The novel has been narrated in flashback technique. The use of dreams 
portrayed in the novel by Deshpande has successfully put forward Jaya's mental situation .This technique is viewed by Y.S. Sunita Reddy as, "The narrative with its slow unknotting of memories and unraveling of the soul reads like an interior monologue quite similar to the stream of conscious technique employed by the like of Virginia Woolf" (3).

Jaya's introspection and self-analysis commence after moving to Dadar flat as in the case with Sarita and Indu whose introspection is occasioned by death of Sarita's mother and Indus's grandmother's aunt Akka. Jaya after her self-appraisal is quite a winner as she has understood her different roles as a daughter, wife, daughter-in-law, mother and a writer. Traditionally, a woman has an identity only as husband's wife' or as father's daughter. Thus, the point, here, raised by the novelist is that a woman is always defined and redefined with reference to men only. Jaya says "I was born. My father died when I was fifteen I got married to Mohan I have two children and I did not let a third live" (2).

Jaya was traditional role of a woman, wife and mother has suppressed her existential self. Though she has a happy home with his well earning husband and two children-Rati and Rahul and material comforts, she feels fed up with the monotony and fixed pattern of her life "worse than anything else had been the boredom of the unchanging pattern, and unending monotony" (4). In her attempt to rediscover her true self, she finds herself as an unfulfilled wife, a disappointed mother and a failed writer. Pushpa Iyenger while reviewing the novel for the 'Times of India', observes that "Jaya caught in an emotional eddy, endeavors to come to terms with her protean roles, while trying albeit in vain, to rediscover her true self, which is but a ephemera of unfulfilled wife, a disappointed mother and a failed writer" (2).

Jaya also undergoes certain traumatic experience in her life and she became totally changed and then expects to have a new relationship with her husband. She had numerous dreams about her life. She expects that, after getting married her life attain a new path but unexpectedly her husband could not understand her feeling as a result of which she was torn from within. Deshpande uses a beautiful image to describe Jaya's married life "A Pair of bullocks yoked together ... a clever phrase, but can it substitute for the reality? A man and a woman married for seventeen years a couple with two children"(8).

Here, 'pair of bullocks yoked together' means a world of meanings. Bullock means that the bullocks so yoked and shared the burden between themselves but no one knows whether they love each other or not. The image of the beasts performing the duty mechanically undermines the husbandwife relationship, which is united in marriage for love and not for leading a mechanical life terminating in mutual hatred and distrust. Jaya resents the role assigned to a wife in our country, who is called upon to stay at home and look after the babies and keep out of the rest of the world. Jaya is a good writer but she could not continue her writing because her Mohan discouraged her. "I gave up my writing because of you (143)". She said to Mohan.

Once Mohan accepts the illegal gratification to become rich and to lead a comfortable of life. He said to her, "I wanted you to have a good life. I wanted the children to have all those things I never had" (9). Mohan, who is disturbed because of the final disgrace which the enquiry will bring, takes excuse by saying that he has engaged in malpractices to keep his wife and children comfortably by saying "I did it for you, for you and the children"(10).This creates a real sense of anger in Jaya.

Mohan always insults Jaya, not only her behavior but also her appearance though Jaya accepts his insults and her new identity and she tries to remain "Smiling, placid, and motherly woman, a woman who lovingly nurtured her family. A woman who coped" (16). Jaya also cuts her hair and adopts the life style of Mohan as he wishes and she also maintains her friendly relationship with the people who ever Mohan invites to the house. Jaya does not want to break the bonds of the family but tries to find happiness and fulfillment within the family. Mohan never accepts her as Jaya (victories) after her marriage to Mohan but he remains as "Suhasini" which means "soft, smiling, placid motherly woman" (16). Ever since she is named as Suhashini, she feels that her identity is in dilemma and feels disoriented. 'Suhashini' becomes the symbol of pain taking and fastidious house wife, to only care and look after her children, maintain the home well in order. Like Bharati Mukherjee's protagonist Jasmine loses her identity by being called by several names, Jaya also loses herself and identity. Jaya is totally changed after her marriage and she never raised any opposition against Mohan. Even in her writings, her inner voice is never revealed and this feeling went deep into her and she became neurotic position. Jaya also reminded of her aunt's advices before her marriage and it always flashes in her mind and this makes her to control her image as a traditional wife. Her aunt Vanitamami advises her before her marriage and she says, "Remember Jaya, a husband is like a sheltering tree... Keep the tree alive and flourishing, even if you to water it with deceit and lies" (32). 
Mohan is a typical patriarchal husband but not openly authorization with Jaya. To him, wife is exclusively husband's property and therefore can be used as a status symbol to be flaunted. His image of an ideal wife is a result of his observance of the submissive women that he has seen in his family during his growing years, and he expects Jaya to behave in a similar manner.

Mohan also once said to her that, "My mother never raised her voice against my family, however badly he behaved to her, he had said to me once" (83).Therefore Jaya maintains her image as a traditional wife and tries to sacrifice anything for her husband. The thought of the desertion by the husband unnerves Jaya for she has not yet cast off the role of a traditional Indian Woman. Through Jaya's character, Deshpande expresses an ambivalent attitude of contemporary educated independent minded Indian women who can neither reconcile themselves to a situation when their husbands ignore them and crush their ambition in life nor can they cast off their husbands, for the husbands is like a sheltering tree, which they can't afford to live without. Shashi Deshpande suggests that marriage is based on convenience not on love, and also she suggest that role of Gandhari, which is revealed in the novel through Jaya's articulation:

"If Gandhari, who bandaged her eyes to become blind like her husband, could be called an ideal wife, I was an ideal wife too..." (61).

Jaya enjoys her intimate friendship with Kamat by sharing her opinion and ideas about her stories which she could not do with Mohan. She admires him for treating her as his equal and only in his presence she can be in her own self. No doubt Mohan encourages her to write but the way he expects. Her writing is also a kind of breaking the silence. Rajeswari SunderRajan argues, "Deshpande's protagonist breaks her silence at one level through the act of writing itself, at another level through renegotiating interpersonal relations within the family" (4).

Jaya is also aware that the society will not acknowledge the relationship between the outside man and the woman after marriage, even though she maintains her relationship with Kamat. Jaya realizes that Kamat is dead she says, "That night, while having dinner, I had thought, someone I know is dead, I saw him dead. And I had been detached from that woman who had seen him, remote from that experience" (157).

Jaya feels herself totally lost as she is taken for granted by Mohan. She realizes that her own feelings and emotions don't mean anything to him. Her realization that she is a nonentity in his eyes hurts her. In earlier incidents when her paternal uncle Ramu kaka shows her the family tree wherein even boys of the family find mention but her name is missing. She questions this patriarchal family tree at which he says: "How can you be here? You don't belong to this family. You have no place here" (142-43). Jaya is also shocked to find no mention of her mother, her aunts and even Ajji who kept the family together. She is full of anger and desperation over such gross gender discrimination.

Deshpande points out that silence and surrender are considered as virtue of women in the patriarchal Indian society. Despondency state seems to be the common factor in the mode of suffering in the case of both Mohan's mother, Vimala, Nayana, Jeeja, Kusum, Tara. Mohan's sister Vimala had an ovarian tumour with metastases in the lungs. She does not disclose it to anybody in the family. And ultimately she dies a silent death like her mother who died while trying to get her baby aborted with the help of the midwife.

Kusum, a relative of Jaya was in a very dejected mood forsaken by her husband. She was almost insane. Jaya took pity on her and brought her to her own house and took care of her to give solace and comfort to her. Yet she committed suicide not able to overcome her state of rejection and despondency. Even Mohan's mother and his sister suffered and died because they never expressed their emotion and feeling but kept silent, succumbing to their own distress and mistakes.

Tara, another women character of this novel, reached the same destiny as other characters as mentioned above, unable to bear the torture of her drunkard husband. Jaya sees all the life of the women characters and realizes that keeping always silent, not showing any opposition or any resistance, will only lead to a disaster of the women. Who is really responsible for the state of despondency of a woman? It is perceived novels that women are themselves the true cause for the despondent state. Rather than the circumstances they face or the members of the family. Thus, the novelist brings to the surface the gender-bias which is prevalent in the Indian society.

Jaya's self-examination of her married life has brought to light that she is partly responsible for the loss of her real self. The seventeen years of their married life brings boredom, dullness and monotony instead of intimacy and friendliness. In her effort to be an ideal wife she loses her life in the name of sacrifice. Her failure to be an ideal wife and mother is revealed by her "I've failed him (Mohan). He expected something from, me from his wife, and I've failed him" (185). 
This kind of self realization helps her to find the reason for the unhappy married life. She understands the consequences of suppressed anger. Her silence is nothing but suppressed anger. Silence or lack of communication is the cause of marital incompatibility. She decides to break her long silence to restore peace and happiness. She decides "to plug that hole in the heart, I will have to speak, to listen, I will have to ease that long silence between us" (192). She decides to be assertive and to be her own self. S. P. Swain observes that "The tragic predicament of the Deshpande's protagonist is the outcome of male-domination in a patriarchal culture. Their silent suffering is socio-psychic in nature" (5).

Once Mohan's disappearance from the house, Jaya gets the news that her son Rahul disappeared while holidaying. Jaya is in totally dejected state and there is no one to help at this stage. Jaya is reminded of Lord Krishna's sermon in Bhagwad Gita, "I have given you knowledge. Now you make the choice. The choice is yours. Do as you desire" (192). These lines remain in her thought and give her some courage. The self-confidence in Jaya has gone far from her, when her husband leaves the home without informing her and Rahul is also disappeared. She receives a telegram from Mohan and Rahul will come back to the house. She felt happy and she recalls her experience and undergoes some suggestion and decided not to be passive and silence.

Towards the end of the novel, Jaya emerges as a determined strong-willed modern woman, who is prepared to face life, accept her responsibilities squarely and tries not to escape from or avoid them. Jaya observes that meaningful coexistence of man and woman can come only through understanding, respect and compassion not through domination or subjugation. Choice is the right of both man and woman. The only thing to remember is that choice is relevant only when there is responsibility to one self. Freedom is to survive 'as a whole' within the system, and Jaya ultimately feels that it is possible. Usha Thambe remarks that, "The confused and clumsy Jaya appears a contrast to the smiling, efficient housewife Suhasini... (127)".

Jaya finally understands that she also has contributed to her victimization and that she has to fight her own battle and work out her own solution. Accordingly, she feels the necessity to break the silence, articulate her predicament, and establish her identity. She knows that there is always room for discussion and compromise. It is not the fault of men alone that has caused the feminine discontent. A patriarchal order can be subverted if only women take their status on the basis of intelligence and individuality. Jaya feels, as P. Rama Moorthy affirms “... it is possible for a woman to live in the world where men also live" (169).

Therefore in the despondency state, Deshpande is a crusader against suppression of women. She wants companionship between man and woman. Her presentation of the case for equality is convincing. Since she never deviates from hard realities of life, she has chosen to present a picture of women's life in middle and lower sections, believing that they make the bulk. Deshpande depicts her protagonist as a woman with a certain willingness to face the problem in life by her desire to voice her protest as revolutionaries after a long silence. It is her last ditch effort to save herself from isolation and also falling into self preservative negativism issuing directly from psychological representation unleashed by the social institution of family.

Jaya's decision to exercise her rights is a welcome one. She wants to liberate herself by respecting her feeling and desires. Kamini Dinesh finds "Jaya moving out of the 'cloistered self' as she seeks to escape from the struggle of everyday life and is forced to find inner resources that will allow her to return and engage more fully in her life and marriage" (196). Jaya's optimistic view of life that changes are possible exposes the transformation she has undergone. Deshpande exhorts through this novel that women most fight first for their rights. The subjugation of women can be rooted out only if women start breaking their long silence as in the case of Jaya.

\section{REFERENCES}

\section{Primary Sources}

[1] Deshpande, Shashi. That Long Silence. New Delhi: Penguin Publications,

[2] 1989. Print.

\section{Secondary Sources}

[3] Beauvoir, Simone de. The Second Sex. Trans and Ed. H.M. Parshley. New York: Vintage Books, 1974. Print.

[4] Friedan, Betty. The Feminist Mystique. Harmondsworth: Penguin, 1971. Print

[5] Iyenger, Pushpa. "Girls in Salem are Born to Die." The Times of India May 9, 1992.

[6] Iyengar, Srinivasa K.R. Indian Writing in English. New Delhi: Sterling Publisher, 1993. Print.

[7] Kamini, Dinesh. "Moving out of the cloistered self: Deshpande's Protagonists." Margins of Erasure: Purdah in the Subcontinental Novel in English. Ed. Jashbir J 
[8] Reddy, Y.S.Sunitha. A Feminist Perspective on the Novels of Shashi Deshpande. New Delhi: Prestige Books, 2001.51.Print.

[9] Stimpson, Catherine R. "Gertrude Stein and the Transportation of Gender." The poetics of gender. Ed. Nany K. Miller, New York: Columbia UP, 1986. Print. [10] Sunder Rajan, Rajeswari. "The Feminist Plot and the Nationalist Allegory: Home and World in Two Indian Women's Novels in English." Modern Fiction studies. 39.1.1993. Print.

[11] Tambe, Usha. "Shashi Deshpande as a Feminist and a novelist." Sarang and Bharucha. (eds), 1994.115-29. Print. 